\title{
Molla Halil Siirdî’ye (1754-1843) Göre Kabir Hayatı
}

\section{Intermediate Realm (Grave Life) According Mullah Khalil Sïrdî}

\author{
Serkan Tekin ${ }^{\mathrm{a}, *}$ \\ ${ }^{a}$ Dr. Öğr. Üyesi, Serkan Tekin, Tekirdağ Namık Kemal Üniversitesi İlahiyat Fakültesi. \\ ORCID: 0000-0001-5892-8889
}

\section{MAKALE BİLGISİ}

Makale Geçmişi:

Başvuru tarihi: 01 Temmuz 2020

Düzeltme tarihi: 15 Eylül 2020

Kabul tarihi: 22 Eylül 2020

Anahtar Kelimeler:
Kelam
Siirt
Molla Halil
Kabir

\section{ART ICLE INFO}

\section{Article history:}

Received 01 July 2020

Received in revised form 15 September 2020 Accepted 22 September 2020

\section{Keywords:}

Kalam

Siirt

Mullah Khalil

Intermediate realm.
ÖZ

Molla Halil Siirdî, 1750-1843 yılları arasında yaşamış, hayatı, eserleri ve düşünceleriyle yaşadığı devrin ilim ve fikir hayatına yön vermiş önemli âlimlerden biridir. Yazdığı ilmî eserlerle kendi dönemindeki medrese mensuplarının ve ilim çevrelerinin dikkatini çekmiş, hoca ve talebelerin ilim ve fikir dünyalarının şekillenmesinde etkili olmuştur. Biz bu makalede, başta Molla Halil'in kendi eserleri olmak üzere bu konuda yazılmış diğer kitap, tez, madde, makale vb. kaynaklardan yararlanarak onun "Kabir Hayatı" konusuna yaklaşımını inceleme konusu yaptık. Makalenin başında önce Molla Halil'in hayat1, tahsili ve eserleri konularında kısa bilgiler verdik. Sonra "Kabir Hayatı" kavramlarının kelime ve terim anlamları ile mezheplerin bu konudaki görüşlerini tespite çalıştık. Kabir hayatı, insanın öldükten sonra kıyametin kopmasına kadar geçirdiği hayatını kapsar. Molla Halile göre, günahkâr olan mümin öldükten sonra kabirde azap görür. Ancak günahı olmayan mümin öldükten sonra kabirde mükâfat alır. Sorgu melekleri kabirdeki ölüleri sorguya çekerler. Bazı Mutezile âlimlerine göre ise kabir suali de kabir azabı da yoktur.

\section{Giriş}

"Kabir" ya da "kabir hayatı", sadece İslamiyetten sonra değil, İslam öncesi dinlerde de saygın bir mekân olarak kabul edilmiş, tarihin her döneminde insanlar inançlarına, örf ve adetlerine uygun bir şekilde ölülerine veda etmişlerdir. $\mathrm{Bu}$ meyanda kimi zaman yakarak kimi zaman kurda kuşa yem ederek kimi zaman da yüksek ağaç dallarına asarak, ama çoğunlukla toprağa emanet etmek suretiyle ölülerini dünya sonrası hayatın ilk durağı olan kabirlerine emanet etmişlerdir.

Semavî dinler olarak tasnif edilen Yahudilik ve Hıristiyanlıkta ölülerin gömülmesi için farklı ritüeller uygulanmış olsa da her iki inanç mensupları da ölülerini kabirlere defnetmişlerdir. Ölüm ötesi hayata dair kabulleri ve dünya hayatındaki iyiliklerin bir karşılı̆̆ı olarak ahirette inanmışlara mükafatlar verileceği hususu bir inanç esası olarak hem Yahudilik hem de Hiristiyanlıkta mevcuttur;

\footnotetext{
* Sorumlu yazar/Corresponding author

e-posta: serkantekin240681@gmail.com
} 
ancak Müslümanlardakine benzer şekilde bir kabir hayatı inanışı her iki dinde de yoktur. (Demirci 2001: XXIV. 3335).

İslam literatüründe kabir denildiği zaman sadece kuru bir toprak parçası değil, aynı zamanda bu mekanla özdeşleşmiş ve Müslümanların ruh ve fikir dünyasında önemli çağrışımlara yol açan özgün bir hayat durumu da akla gelir. İslam düşüncesinde ölüm mutlak bir yok oluş sayılmamış, kıyamet günündeki dirilişe kadar geçecek olan süre anlamsız bir zaman dilimi gibi görülmemiştir. O sebeple "kabir hayatı" kavramı esaslı ve çatı kavram olarak Müslümanların hayatında yer almış ve farklı İslami disiplinler içerisinde bu kavram etrafinda şekillenen pek çok konu tartışılagelmiştir. Nitekim kelâm literatüründe kabir hayatıyla ilgili "kabir sorgusu", "kabir azabı" ve "kabir nimetleri" merkezinde üç temel mesele tartışılagelmiştir. (Toprak 2001: XXIV. 37-38). Makalenin ilerleyen safahatında inceleme konularımızın bu meselelere yoğunlaştığı görülecektir.

Bitlis'in Hizan ilçesine Bağlı Süttaşı (Kulpik) köyünde 1750 yılında dünyaya gelen Molla Halil Siirdî’nin Müslüman ulemanın dikkatli tetkiklerine mazhar olan "kabir hayatı" ve bu hayata müteallık temel meselelere dair görüşlerini değerlendirmeye tabi tutan makalemiz, özellikle halk üzerindeki tesirleri açısından yaygın inanç konularındaki kabullere yön veren önemli bir âlimin, kendi döneminde Doğu Anadolu bölgesinin ilmî hayatında derin izler bırakmış bir medreselinin bahse konu tartışmalarla alakalı görüşlerini incelemektedir. Sünnî düşünce ekseninde geliştirildiği açık olan bu görüşlerin mahtût nüshalara referansla literatüre geçirilmiş olması, makaleyi bilimsel açıdan değerli kılan bir husus olarak değerlendirilebilir.

\section{Kabir Hayatına Dair Kavramsal ve Tarihsel Çerçeve}

Kökeni itibarı ile Arapça bir kelime olan kabr, "gömmek, defnetmek" anlamında mastardır. (İbn Düreyd 1987: I. 324). "Ölünün gömüldüğü yer" için de mef’ûl manasında masdar olan "kabr", "makbere" yahut "makbure" kelimeleri kullanılır. Kelimenin çoğulu "akbur", "kubûr" ve "mekâbir" formlarında gelir. (Cevherî, 2009: 911, Firûzabâdî, 2008: 1280). Kur'ân-1 Kerîm'de "kabr" şeklinde tekil halde bir yerde, (Tevbe 9/84) "mekâbir" ve "kubur" şeklinde çoğul halde toplam altı yerde (Tevbe 9/84) geçer. Kur'ân'da bir yerde ise if'âl babında "akbera" şeklinde kullanılmıştır ki (Abese 80/21) Ebu Ubeyde ve Ferâhîdî âyetteki ifadenin "Sonra onu öldürdü ve kabre konulmasını emretti" anlamına geldiğini belirtir. (Ebu Ubeyde II. 386; Ferâhîdî. 2003: III. 352). Âyette Hâbil'in bir kargadan aldığ dersle kardeşinin bedenini gömmesine (Mâide 4/31) işaret bulunmaktadır. Demek ki insanların kabre konulması uygulaması insanoğlu tarafından ilahî bir yönlendirme sonucu keşfedilmiştir.

Istılahî anlamda kabir, insanoğlunun öldükten sonra kıyamete kadar geçirmiş olduğu yere verilen addır. Ölüm sebebiyle ruhun bedenden ayrılmış olması, ölenin hayatta olanlarla irtibatının engellenmesi, ölümün geride kalanlara acı vermesi, dostlarından ayrılmanın ölen kişiye zor gelmesi, kabirde bedenin çürümesi, ruhun sıkıntı yaşaması, bedenden ayrıldıktan sonra tekrar ahirette buluşuncaya kadar dünya ve ahiret hayatı arasında kabrin perde olması münasebetiyle tüm bu zaman dilimi "kabir hayatı" ismiyle anılmıştır.

Lügavî olarak iki şeyin arasındaki perde, ölümden kıyamete kadar olan süre, iki deniz arasındaki kara parçalarını birbirine bağlayan dar kara parçası, şek ve yakin arasındaki durum ve ada anlamlarına gelen "berzah" kelimesi de (Cevherî 2009: 87) kaynaklarımızda dünya ve ahiret hayatı arasındaki dönemi anlatmak üzere "berzah âlemi" şeklinde kullanılmıştır. Kur'ân-1 Kerîm'de aynı manayı ifade edr tarzda, "Nihayet onlardan birine ölüm gelip çatınca, 'Rabbim, beni geri gönder de dünyada iyi işler yapayım' der. Hayır! Onun söylediği bu söz boş bir laftan ibarettir. Artık onların önünde, yeniden diriltilecekleri güne kadar bir berzah vardır." (Mü'minûn 25/99) buyurulmuştur.

Kabir ve ilgili konular bağlamında sık kullanılan bir başka kavram da "kabir azabı"dır. Yemekten içmekten kesilmek, bir şeyden menetmek, hapsetmek, eziyet etmek, işkence etmek, korkutmak, insana zor gelen her şey, tatlı ve temiz su (İbn Fâris 1989: IV. 259-260; Cevherî 2009: 744) anlamlarına gelen azap kelimesi, özellikle kabir azabı münasebetiyle kelam kaynaklarında sıkça tartışma konusu olmuştur.

Kabir hayatının varlığına inanan ulema arasında bu hayatın mahiyetine dair farklı görüşler ileri sürülmüştür. Seyyid Şerif Cürcânî, kabirde ölülerin diriltileceğini, sorgulanacağını ve kâfirlerle günahkâr müminler için kabir azabının söz konusu olacağını kabul eder. (Cürcânî 1971: 8/345). Taftazânî de "Allah o mümini, onların kurdukları tuzakların kötülüklerinden korudu. Firavun'un adamlarını ise o kötü azap kuşattı. Onlar, sabah akşam ateşe arz olunurlar. Kıyamet kopacă̆ gün de 'Firavun hanedanını azabın en şiddetlisine tıkın!' (denilecektir) (Mü'min 40/4546)." âyetine dayanarak kabir azabının ve sorgusunun hak olduğunu ileri sürer. Ayrıca "Kâfirler diyecekler ki: 'Ey Rabbimiz! Sen bizi iki defa öldürdün, iki defa dirilttin. Şimdi günahlarımızı anladık. Fakat çıkmaya bir yol var $m \imath$ ?' (Mü'min 40/11)" âyetindeki ikinci diriliş de Taftazânî’ye göre kabirde gerçekleşecektir. (Taftazânî. 1998: III. 361).

İnsanoğlunun kabirde nasıl bir canlılığa sahip olacağ konusunda da farklı görüşler bulunmaktadır. Kabir hayatının varlığını kabul eden ehl-i sünnet âlimlerinin çoğunluğuna göre kabirdeki hayat, bedene, kabirde göreceği azabı ya da erişeceği nimetleri hissedebileceği kadar ruh verilmesi şeklinde olacaktır. İnsanoğluna kabir hayatında verilen canlılık, dünya hayatında olduğu gibi fiilleri tam anlamıyla yapmaya muktedir olacağı güçte bir hayatiyet değildir. (Cürcânî 1971: VIII. 345). Sadece ruh ile bedenin birbiri ile zayıf düzeyde irtibat kurması anlamında bir canlılıktır. Çünkü ölümden sonra ruhun bedenden ayrıldığını herkes kabul etmektedir. Esasen ruhun bedenden ayrılıp berzah âlemine kapatıldığı konusunda açık âyet de bulunmaktadır. (Müminun 23/99-100.) O halde çok sayıda hadis-i şerifte kabir hayatına dair anlatılanlar, bahse konu berzah âlemindeki ruh ile çürümüş dahi olsa kabirdeki beden arasındaki hiç kopmayan, mahiyeti bizce meçhul irtibatı ifade etmektedir.

Yukarıdaki paragrafta anlatılanları izah sadedinde ulemanın çeşitli açıklamaları mevcuttur. Örneğin İbn Ebi'l-İzz ruh ile beden arasında ana rahmi, dünya hayatı, uyku hali, berzah ve ahiret hayatı olmak üzere beş ayrı safhada beş farklı 
ilişki olduğunu savunur. Ona göre kabirdeki hayat ile uykuda yaşadığımız hayat birbirine benzer. Her iki halde de ruh bedenden çıkar, ama uykuda yaşananların bedeni de etkileyeceği güçlü bir duygu halinde ruh-beden irtibatı devam eder. (İbn Ebi’l-İz 1401/1981: 390-391). İbn Hacer el-Askalanî ise bir insan ruhunun bedene girmeden de beden ile mutlak surette bir irtibatının devam edeceğini savunur. (Askalânî 41). Süyûtî, kabir hayatında iyi ruhların illiyyîn adı verilen bir yere, kötü ruhların ise siccîn adı verilen bir yere gideceğini söylese de ruhu ile beden arasındaki bağın kopmadan devam edeceğini iddia eder. (Suyûtî 1985: 16).

Kelam kitaplarında şahit olunan bilgi yanlışlıklarından birisi de genel olarak Mu'tezilî kanadın kabir azabını kabul etmediği şeklindeki iddiadır. (Pezdevî 1980: 235). Cürcânî; Dırâr bin Amr, Bişr el-Merrîsî ve son dönem Mutezile âlimlerinin çoğunun kabir azabını, kabirde dirilmeyi ve sorgu melekleri tarafindan sorgulanmayı inkâr ettiğini aktarır. (Cürcânî 1971: VIII. 346). Eş'arî de "el-İbâne" adlı eserinde, onların kabir azabını kabul etmediğini söylemektedir. (Eş’arî 1409: 215). Ne var ki bu iddialar Mu'tezile'nin tamamı göz önüne alındığında kesin olarak yanlıştır; ancak bu yanlış, kasıtlı olarak ya da bilgi eksikliğinden, günümüzde de muhtelif mahfillerde dile getirilmektedir. Duveyhî tarafindan H.1412 yılında Riyad Şerîat Fakültesinde pekiyi dereceyle tamamlanan ve müteaddit defalar basılan "Ârâu'l-Mu'tezile el-Usûliyye" adlı doktora tezinde de aynı hata tekrarlanmıştır. Bu tezde Mu'tezile'nin kabir azabını reddettiği söylenmekte, üstelik bu iddia Mu'tezile hakkındaki en önemli kaynaklardan Kâdî Abdulcebbâr'a dayandırılmaktadır. (Duveyhî. 1996: 75). Oysa ilgili doktora tezinde kaynak olarak gösterilen yerlerde Kâdî Abdulcebbâr, kendilerine bu konuda iftira atıldığını dile getirerek kabir azabını bütün bir Mu'tezile'nin reddettiği fikrine karşı çıkmaktadır. Aslında kabir azabını Dırâr b. Amr'ın inkâr ettiğini, ancak Dırâr'ın, Vâsıl b. Atâ'nın ashabından olması sebebiyle bu ithamın Mu'tezile'ye yöneltildiğini söyler. Mu'tezile'nin bu konuda iki gruba ayrıldığını; bir grubun rivayetlerdeki şekliyle kabir azabını kabul ettiğini, diğerlerininse ölü olarak kabirdekilerin azap görmeyeceği kanaatinde olduğunu nakleder; çünkü onlara göre ölüler duyamaz, işitemez. Yine onlara göre birçok varyantla gelen bu haberlerde kastedilen, ölünün son dakikalarında yaşadığı azaptır. Kâdî Abdulcebbar ise kabir azabının varlığını kabul eder. Hatta beşerden efdal olarak nitelendirdikleri meleklere MünkerNekîr gibi nâhoş adların verilmesini bile makul görürken aslında bu inancını tekrar etmiş olur. (Kâdî Abdulcebbâr 1974: 201-202). Hâsılı Mu'tezile hakkında bu tür ithamlar yakıştırmadan ibarettir. Belki de bu konuda en objektif tutum, kabir azabı konusunda bir grup Mu'tezilînin genel kabulden farklı bir yolu benimsemiş olduklarını söylemek olmalıdır. Nitekim Makrizî (845/1441), Mu’tezile'den bir grubun (Kabriyye) böyle düşündüğünü naklederken (Makrizî. II.348) sanırız bunu kast etmektedir. (Polat 2009: 379-381).

Kabir hayatını reddeden ilim adamları, kabir adı verilen yerde fizikî anlamda herhangi bir yaşam belirtisinin bulunmamasına dair iddialarına delil getirmişlerdir. $\mathrm{Bu}$ hayatı tasvir eden, detaylarından bahseden sarih bir nas olmayışı da onları bu fikirlerinde ısrarcı olmaya itmiştir. $\mathrm{Bu}$ hususta dayandıkları delil ise "Illk tattıkları ölüm dışında, orada artık ölüm tatmazlar. Ve Allah onlarl cehennem azabından korumuştur (sürekli hayata kavuşmuşlardır). (Duhân 44/56-57)" âyetidir. Şayet kabirde herhangi bir formuyla dirilme, canlılık söz konusu olsaydı o zaman bu âyete göre kıyamet kopmadan önce kabirdekilerin bir daha ölümü tatmaları gerekirdi. Mesela İbn Sînâ gibi bazı filozoflar dünya hayatına benzeyen bir kabir hayatının mevcudiyetini reddetmişlerdir. İbn Sînâ'ya göre hem beden hem de ruh aynı anda ölmektedir; gerçek anlamda ölümsüz olan varlık ise insanın nefsidir. İnsan nefsi, akl-ı sanî olan nefs-i küllîden geldiği için bedenin ve ruhun ölmesiyle bu nefis tekrar geldiği yere dönmektedir. (İbn Sina II. 70; Toprak 1989: 213-464).

Kabir hayatını reddedenlerin "Illk tattıkları ölüm dışında, orada artık ölüm tatmazlar. Ve Allah onları cehennem azabindan korumuştur (sürekli hayata kavuşmuşlardır) (Duhan 44/56-57)." âyetini delil getirmesi bize göre doğru değildir. Çünkü ehl-i sünnet uleması kabirdeki dirilmeyi ve yaşamayı dünya hayatındakine benzer şekilde tam bir dirilme ve tam bir yaşama olarak görmemekte, bir tür uykudaki canlılık hissine benzetmektedir. Dolayısıyla bu dirilme tam dirilme sayılmaz ki ölümü de tam ölüm sayılsın. $O$ sebeple bu âyette sadece ölümden bahsedilmiştir.

Aynı şekilde kabir hayatının varlığına inanmayanların " $E y$ kâfirler! Allah'ı nasıl inkâr edebiliyorsunuz ki sizler ölü idiniz de $O$ sizi diriltiverdi. Sonra sizi öldürecek, sonra tekrar diriltecek, sonra da O'na döndürüleceksiniz (Bakara 2/28)." âyeti ile "Kâfirler diyecekler ki: 'Ey Rabbimiz! Sen bizi iki defa öldürdün, iki defa dirilttin. Şimdi günahlarımızı anladık. Fakat çıkmaya bir yol var mıdır ki?!" (Mü'min 40/11) âyetlerini kendi iddialarına delil göstermeleri ve " $\mathrm{Bu}$ âyetlere göre ikinci diriliş ahirettedir; çünkü eğer kabirde olsaydı o zaman ahirette üçüncü bir dirilişin olması gerekirdi. Oysa âyetlerde üçünü bir dirilmeden bahsedilmemektedir." (Taftazânî 1998: III. 362) şeklinde akıl yürütmeleri de bizce doğru değildir. Bir defa Kur'ân'da iki dirilişten bahsedilmesi üçüncü bir dirilişin olmayacağı manasına gelmez. Çünkü âyette bir sayı verilmiş ise de diriliş sayısının bununla sınırlı olduğu ifade edilmemiştir. Dolayısıyla ikisi zikredilen, ancak birisi zikredilmeyen üç dirilişin olması naklen muhâl değildir. Kaldı ki az önce ifade ettiğimiz gibi kabir hayatı, dünya ve ahiret hayatı gibi tam bir hayat olarak görülmediğinden buradaki dirilişi de dünya hayatına doğma ya da ahirette yeniden diriltilme ile bir tutmamak gerekir

\section{Molla Haliı Siirdî’ye Göre Kabir Hayatı}

\section{1. Kabir Hayatı}

Molla Halil'e göre, naslarda bildirildiği kadarı ile insanın dirilişiyle ilgili altı merhale söz konusu olmuştur.

Birinci merhale, Allah'ın insanları Hz. Âdem'in belinden zerreler gibi çıkarıp onlara ben sizin rabbiniz değil miyim, dediği merhaledir. Kur'ân'da bu konuda Allah şöyle buyurmaktadır: "Hani Rabbin Âdemoğullarından, onların sırtlarından zürriyetlerini çıkarıb kendilerini de bizzat kendilerine şahit tutmuş ve 'Ben sizin Rabbiniz değil miyim?' (demişti). Onlar da 'Evet, (Rabbimizsin), şahit olduk' demişlerdi. (İşte bu tanıklık), klyamet günü 'Bizim bundan haberimiz yoktu' dememeniz içindi (A'râf 7/172)."

Ikinci merhale ise insanların bir anne babanın evladı olarak bu dünyaya gelmiş olmaları halidir. 
Üçüncü merhale ise Münker-Nekîr'in sorgu için geldiği anda insanın kabirde diriltilmesidir. Kabirde bedene ruh verilmesi yukarıda Molla Halil'e göre bazı âyetlerde işareten, birçok hadiste ise sarahaten zikredildiği için kelam âlimlerinin çoğunluğu tarafindan kabul edilmektedir.

Dördüncü merhale İbrahimî diriliş diye adlandırılan, Hz. İbrahim'in Kabe'yi inşa edip, inananları hacca davet ederek harekete geçirilmesidir. Hakiki anlamda olmasa bile bu da manen diriliştir. Özellikle konumuz dikkate alındığında dirilişin manevî bir türü de olduğunu göstermesi bakımından bu merhale önemlidir. Çünkü kabirdeki hayatı tanımlarken dünyadaki hayata benzemediği söylenir. (Molla Halil 2013: 174).

Beşinci merhale Muhammedî diriliş diye adlandırılan, inananların yeniden hayat bulmasıdır. Cehalet batağına saplanan insanların Hz. Muhammed elçiliğinde gelen İslam ile hayat bulması, ölmüş insanlığın dirilişi gibi değerlendirilir. İbrahimî diriliş için söylenenler Muhammedî diriliş için de geçerlidir.

Altıncı merhale ise İsrafil'in ikinci defa sûra üfürülmesiyle yaratılanların tamamının ahiret hayatını başlatan ebedî diriliştir. (Molla Halil 2013: 174).

Molla Halil'e göre insanların hayat sahibi olmalarının yanı sıra melekler ve hayvanlar için de farklı hayat kategorileri vardır. Melekler için birincisi dünya hayatı ile ondan sonraki ölüm ve ikincisi ahiret hayatı olmak üzere iki hayat vardır. Hayvanlar için ise birincisi dünyevî hayat ve dünyadaki ölüm, daha sonra kısas için diriltilme ve en nihayet toprağa dönüş olmak üzere iki ölüm ve iki hayat vardır. (Molla Halil 2013: 174). Hülasa kabrin kendine özgü bir hayatı ve bu hayatta yaşanacak korkulu süreçler vardır. (Molla Halil 28). Üstelik kabir hayatındaki tüm bu dehşetengiz tecrübeler İslam ümmetinin makamını yüceltmek ve müminlerin kıyamet günü yaşaması muhtemel korkularını hafifletmek amacına matuf ilahî bir lütuf olarak görülmelidir. (Molla Halil 2013: 173).

\section{2. Kabir Suali}

Kabirde hangi suallerin sorulacağ ${ }_{1}$ hususunda çeşitli görüşlerin bulunduğu ve bu suallerin iki melek tarafindan kabirdekine yöneltileceği hususu birçok kaynakta zikredilmiştir. Ebu Hüreyre'den nakledilen bir rivayete göre Hz. Peygamber şöyle buyurmuştur: "Cenaze toprağa konulduğu zaman ona siyah ve yeşil renkli iki melek gelir. Birisine Münker, diğerine Nekîr denir (Tirmizî 1071)." Taftazânî ve Cürcânî'ye göre de kabir deki sorgu meleklerinin adı Münker ve Nekîr'dir. (Taftazânî 1998: III. 362) (Cürcânî 1971: VIII. 345).

Cübbâî ve Belhî gibi alimler ise sorgu meleklerinin adının Münker ve Nekîr olarak isimlendirilmesine karşı çıkmış, bu isimlerin onlara ait olmadığını ileri sürmüşlerdir. (Komisyon 1971: IV. 355). Kimi âlimler de Münker ve Nekîr'in iki meleğin özel adı olmadığını, sorgu meleklerinin bu isimle anıldığını savunmuşlardır. Çünkü dünyada aynı anda çok sayıda insan vefat etmekte ve farklı mekanlarda aynı anda birçok mevtanın sorgusu yapılmaktadır. (Komisyon 1971: IV. 356).

Molla Halil'e göre kabirde Münker ve Nekîr adında iki meşhur melek insanları sorgulamakla vazifelendirilmişlerdir. (Molla Halil 2013: 173). "Allah, iman edenleri hem dünya hayatında hem de ahirette sağlam bir söz üzerinde tutar; zalimleri ise saptırtr. Allah dilediğini yapar" (İbrahim 14/27) âyetindeki "sağlam söz", Molla Hail'e göre, kabir sorgusuna karşı müminlerin vereceği cevaptır. Nitekim Berâ b. Âzib (r.a.)'den bu âyet münasebetiyle nakledilen bir rivayette Hz. Peygamber şöyle buyurmuştur: "Müslüman kabirde sorguya çekildiği zaman Allah'tan başka ilâh olmadığına ve Muhammed'in Allah'ın elçisi olduğuna şehadet eder. İşte bu şehadet, Kur'ân-1 Kerim'deki “Allah, iman edenleri hem dünya hayatında hem de ahirette să̆lam bir söz üzerinde tutar (İbrahim 14/27)." âyetinin delâlet ettiği manadır (Buhârî, 1992: "Cenâiz", 87, "Tefsîru sûre" (14) 2; Müslim, "Cennet", 73).”

Ehl-i sünnetin çoğunluğuna göre kabir suali, "Bu ümmet kabrinde imtihan edilecektir (Müslim, "Cennet", 67)." hadisinde ifade edildiği üzere İslam ümmeti için yaşanılacağına inanılan bir gelecektir. Yukarıda zikrettiğimiz gibi aslında bu durum İslam ümmetinin makamını yüceltmek ve müminlerin kıyamet günü yaşaması muhtemel korkularını hafifletmek amacına matuf ilahî bir lütuftur. (Molla Halil 2013: 173). Hatta küfrü sarih olan kişiler için kabir sorgusuna gerek olmadığı da ifade edilmiştir.

Molla Halil Siirdî, her ne şekilde ölmüş olursa olsun tüm insanların sorgulama işleminden geçmek zorunda olduğunu belirttikten sonra peygamberlerin, meleklerin, çocukların ve buluğ çağından önce delirmiş olup da buluğdan sonra delilik halleri devam edenlerin kabir sorgusuna tabi tutulmayacağını belirtmiştir. (Molla Halil 2013: 173). "Allah yolunda öldürülenleri sakın ölüler sanma! Bilâkis onlar diridirler; Allah'in, lütuf ve kereminden kendilerine verdikleriyle sevinçli bir halde Rableri yanında rızıklara mazhar olmaktadırlar. Arkalarından gelecek ve henüz kendilerine katılmamış olan şehit kardeşlerine de hiçbir keder ve korku bulunmadiğ duymaktadırlar (Âl-i İmrân 3/169-170)." âyetine ve bazı sahih hadislere göre şehitler için de kabir sorgusu söz konusu olmayacaktır. Onlara telkin verilmemesinin sebebi de budur. Molla Halil'e göre siddîklerin mertebesine ulaşanlara da kabir sorgusu yoktur. Çünkü sıddîkiyet mertebesi şehadet mertebesinin üstündedir. Cuma günü ölenlere ve "Mülk sûresi kabir azabına karşı bir engel ve bir kurtarıcıdır, insanı kabir azabından kurtarır (Tirmizî, “Fezâilü'l-Kur'ân”, 9; Ebu Dâvûd, "Salât” 327)." hadisi ile “Kur'ân'da otuz âyetten ibaret bir sûre bir adama şefaat etti; neticede o kişi bağışlandı. O sûre, Tebârekellezî biyedihi'lmülk sûresidir (Sicistânî, 1992: 327)." hadisinde ifade edildiği üzere her gece Mülk sûresini okuyan kişiler için de kabir sorgusu ve kabir azabı olmayacaktır.

Kabir sualleriyle ilgili Siirdî'nin gündemine aldığı iki konudan biri bu suallerin hangi dilde olacağına dair meşhur meseledir. Esasen bu konu tüm dinlerde, hatta Sanskritçe, Latince, İbranice gibi önde gelen birçok dil ailesine mensup milletler arasında öteden beri tartışılagelen bir hadisedir. Molla Halil'e göre rivayetlerde belirtildiği üzere cennet ehlinin dili Arapça olacağından kabirdeki sorgulamanın da Arapça olması daha doğru olsa gerektir. Genel kabule rağmen sualin Arapça dışında bir dille, Süryânîce olacağını söyleyen âlim ise Abdurrahman b. Ömer el-Bulkînî'dir (ö. 824/1421). Bulkînî bu görüşü, İsrafil'in sûr borusunu çalmasıyla ilgili uzun bir hadiste geçen şu ifadeye 
dayanarak ileri sürmüştür: "Onlar oradan hepsi de otuz üç yaşında gençler halinde hasredilirler. O gün konuşulan dil Süryanîcedir (Mervezî I. 45)." Molla Halil ise hadisin bu kısmındaki ifadeye dayanarak Bulkînî'nin böyle bir sonuca varmasını uygun bulmaz. Çünkü burada bahsedilen olay sadece sûra üfürülen güne özgü bir durum olabilir. (Molla Halil, 2013: 175).

Molla Halil'in kabir sualiyle ilgili olarak eserinde konu edindiği ikinci husus suallerin içeriğine dairdir. Yaygın ehli sünnet inancinda olduğu şekliyle ona göre de kabirde sorgu melekleri "Rabbin kimdir, dinin nedir ve peygamberin kimdir?" suallerini yönelteceklerdir. Mümin kişi "Rabbim Allah, dinim İslam, peygamberim Muhammed Mustafa (s.a.v.)'dır." şeklinde cevap verecek; günahkâr müminler salih müminler kadar kolay cevap veremezken münafiklar sorular karşısında cevapsız kalacaktır. (Molla Halil 2013: 173)"

\section{3. Kabir Azab1}

Molla Halil'e göre kabir azabının kâfirler ve günahkâr müminler için olacağı hususunda şüphe yoktur. Çünkü bu konuda hem âyetten hem hadislerden yeterince delil vardır. (Molla Halil 2013: 172). "Allah o mümini, onların kurduklarl tuzakların kötülüklerinden korudu. Firavun'un adamlarını ise o kötü azap kuşattı. Onlar, sabah akşam ateşe arz olunurlar. Klyamet kopacă̆ gün de 'Firavun hanedanını azabın en şiddetlisine tıkın!' denilecektir (Mü'min 40/46)." âyeti ona göre kabir azabının varlığına delildir. Çünkü ahirette sabah ve akşam gibi zaman kavramları yoktur. Ayrıca âyetin kıyamette olacak şiddetli azaptan haber veren kısmı, başta geçen azabın kıyametten önceki bir aşamada, yani kabirde olacağını göstermektedir.

Bize göre şu iki âyeti de yukarıdaki âyette var olan manayı tahkim eder tarzda anlamak ve bunların da kabir azabına işaret ettiğini söylemek yanlış olmaz. "Gerçek şu ki zulüm işlemeye şartlanmış olanları, [öteki dünyadaki korkunç azaptan] daha yakın bir azap beklemektedir: ama çoğu bunun farkında değil (Tûr 52/47)." âyeti Siirdî'ye göre de kabir azabının varlığını göstermektedir. Ayrıca "Bunlar, günahlarl yüzünden suda boğuldular, ardından da bir ateşe sokuldular ve o zaman Allah'a karşı yardımcilar da bulamadılar (Nûh 71/25)." âyetini de kabir azabının varlığına delil sayar. Çünkü ona göre, bu âyette tufanda boğulan inkârcılar daha sonra ateşe atılmışlardır. Buradaki ateş ile kıyametteki azap kastedilmiş olamaz; çünkü tufandan sonra kıyamet kopmamıştır. O halde tufanın ardından azap gördükleri "bir ateş", kabir azabı olmalıdır. Aynı şekilde "Hem çevrenizdeki bedevilerden münafiklar var hem de Medine halkindan münafiklıkta israr edenler var. Sen onları bilmezsin; ama biz onlar biliriz. Onları iki kere azaba uğratacă̆ız. Daha sonra da büyük bir azaba itilecekler (Tevbe 9/101)." âyeti de açık biçimde ahiret azabından önce gerçekleşecek bir azabı, yani kabir azabını anlatmaktadir.

Molla Halil yukarıdaki âyetleri zikrettikten sonra bu manayı ve kendisinin sahip olduğu kanaati pekiştirmek üzere kabir azabının varlığını açıkça belirten hadislere de yer verir ve bu hadislerin mütevatir olduğunu özellikle vurgular. Bir hadiste Peygamber Efendimiz "Kabir ya cennet bahçelerinden bir bahçedir ya da cehennem çukurlarından bir çukur (Tirmizî, "Kıyamet”, 26).” buyurmuşlardır. Kabir cehennem çukurlarından bir çukur olarak vasfediliyorsa o zaman kabir azabının varlığı inkâr edilemez. Hz. Âişe validemiz, “Hz. Peygamber'in namaz kllpp da kabir azabından Allah'a siğınmadığını hiç görmedim (Buhârî, 1992: "Cenâiz" 87)." demiştir.

Kabir azabının hak olduğunu şüpheye yer bırakmayacak biçimde çok daha açık ifadelerle anlatan bir rivayet de şöyledir: 'Resûlullah (s.a.v) Medine-i Münevvere'nin bahçelerinden birinden çıktığı esnada kabirlerinde azap gören iki ölünün feryadını işitti. Bunun üzerine: 'Bu ikisi, kendilerince büyük olmayan birer günah sebebiyle azap görüyorlar. Aslında günahları gerçekten büyük idi. Biri idrarından sakınmaz, diğeri de söz taşır, dedikodu yapardı' buyurdu. Sonra yaş bir hurma dalı istedi. Onu iki parçaya ayırıp birini bir kabrin, diğerini de öbür kabrin başına dikti ve 'bu iki fidan canlı kaldığı müddetçe buradakilerin azabının hafifletilmesi umulur' buyurdu (Buhârî, 1992: "Edeb”, 49, "Vudû", 55-56, "Cenâiz", 82)."

Molla Halil'e göre kabirde azabın olabilmesi için ruhun cesede kâmilen iadesi gerekli değildir. Bir yönüyle dahi ruhun beden ile irtibat halinde olması, örneğin uykudaki irtibat gibi de olsa, kabirde insanın azap görmesi için kafidir. (Molla Halil 2013: 172). Öte yandan Molla Halil'e göre, azap gören bir bedenin bu azabın fiziksel sonuçlarını üzerinde taşıması, örneğin acı sebebiyle hareket etmesi, bir yerden bir yere intikal etmesi de gerekmez. Yanan, boğulan ya da bir canavara yem olan kişi dahi kabir azabı ile muazzep olabilir, ama biz onu fark edemeyiz. Örneğin yılanın kabirde gömülen kişiyi ısırdığı rivayet edilmiştir. Hâlbuki biz bunun farkında olmayız. Peygamber efendimiz de ashabı ile otururken Cebrail ile mülaki olurdu, ancak sahabe-i kirâm onu göremezdi. Biz de ölünün cesedine baktığımızda onun farklı bir hayata sahip olduğunu anlarız; ama kabir azabına dair mevtanın bedeninde herhangi bir ize vâkıf olamayız. (Molla Halil 28).

Kabir suali kısmında zikredilen ve Molla Halil'e sorgusualden muaf tutulan gruplar kabir azabına da duçar olmayacaklardır. (Molla Halil 2013: 172).

\section{4. Kabir Nimetleri}

Kabir hayatı ile ilgili pek çok konuşmada ve yazıda kabrin sıkıntılarını öne çıkaran sözlere ve satırlara rastlansa da esasen kabrin bir diğer yüzü kabir nimetleridir. Cenab-1 Allah mümin kullara da kabirde çeşitli nimetler verir. Aslında konu hakkında kaleme alınan eserlerin çoğunda sadece kabir azabından bahsedilip kabirdeki nimetlerden bahsedilmemesi doğru değildir. Çünkü kabir de nimetlenen kişiler de vardır. (Taftazânî, 2017: 359).

Taftazânî, “Allah yolunda öldürülenleri sakın ölüler sanma! Bilâkis onlar diridirler; Allah'ın, lütuf ve kereminden kendilerine verdikleriyle sevinçli bir halde rableri yanında rızıklara mazhar olmaktadırlar. Arkalarından gelecek ve henüz kendilerine katılmamış olan şehit kardeşlerine de hiçbir keder ve korku bulunmadiğ duymaktadırlar (Âl-i İmrân 3/169-170)." âyetlerini kabirde sadece azap değil, nimetlerin ve mutluluğunda bulunduğuna en önemli delil saymaktadır. (Taftazânî 1998: III. 361).

Kabir nimetlerinin var olduğunu şu hadis de desteklemektedir. "Insan öldükten sonra kabre konulunca, Münker ve Nekîr adında iki melek kendisine gelerek soru soracaklar, iman ve güzel amel sahipleri bu sorulara doğru cevaplar verecekler ve kendilerine cennet kapıları açılarak 
cennet gösterilecektir. Kâfir ve münafiklar ise bu sorulara doğru cevap veremeyecek, onlara da cehennem kapulart açllacak ve cehennem gösterilecektir. Kâfirler ve münafiklar kabirde acı ve sıkıntı içinde azap görürlerken müminler nimetler içerisinde mutlu ve sıkıntısız bir hayat süreceklerdir (Tirmizî, 1992: "Cenâiz" 71)."

Molla Halil'e göre de kabirde itaat eden kullara Allah'ın dilediği ve bildirdiği kadar nimet vardır. Kabirde diriltilmiş olan müminler ise bu nimetlerin lezzetini tadacaktır. Ancak bu lezzet, dünya ya da ahiret hayatındaki gibi kâmilen değil, kısmen hissedilecektir. (Molla Halil 2013: 172). Molla Halil bu görüşüyle de Eş'arî geleneğini takip ettiğini göstermektedir. Molla Halil'in Taftazânî tarafindan şerhleri yapılan o dönemin medreselerinde yaygın olarak okutulan kitaplarından istifade ettiği söylenebilir.

\section{Sonuç}

"Kabir" ve "kabir hayatı", semavî dinlerin tümünde ölüm ötesi hayatın merkezî kavramlarındandır. İslam uleması kelam kitaplarının kabir hayatını konu alan bölümlerinde bu meseleyi ele almış ve ahiret inancının bir parçası olarak kişisel görüşlerini mensubu oldukları düşünce sisteminin esaslarına uygun biçimde ortaya koymuşlardır.

Mutezilî düşünceye mensup ilim adamlarından sayılı birkaç tanesi ve Râfizîler kabirde sorgu-sualin bulunmadığını, kabir azabının söz konusu olmadığını ileri sürerek ilahî azabın yalnızca kıyamet sonrasında, ahiret hayatında vuku bulacağını ileri sürmüşlerdir. Mu'tezile'den Kadı Adulcabbar, kabir azabının varlığına kani olmuş, mezhep içerisinde bunu reddedenlerin Mu'tezile'den ayrılmış isimler olduğunun altını çizmiştir.

Ehl-i sünnet itikadına sıkı sıkıya bağlı kaldığını tüm eserlerinde hissettiren Molla Halil, Eş'arî düşünceye uygun olarak ölümle birlikte kabir hayatının da başladığını savunmaktadır. Kabre konulan mevtanın ilk misafirleri Münker ve Nekîr adlı iki sorgu meleğidir. Dünyada mümin olarak yaşamış ve ölmüş olanlar "Rabbin kimdir, dinin nedir, peygamberin kimdir" sorularına kolaylıkla cevap verirken günahkâr Müslümanlar büyük zorluklar çekerek bu sorgudan çıkabileceklerdir. İnkârcılar ve itikadî anlamda münafiklar ise bu sorulara cevap veremeyeceklerdir.

Molla Halil'e göre kabir hayatı ruh ve bedenle (rûh maa'lcesed) tecrübe edilir ve bedene, azabı ya da nimeti hissedebileceği kadar ruh iade edilir. Ancak iade edilen bu ruh hislerini harekete geçirse de fiilî olarak bedenin hareket etmesine yeterli gelmez. Bu izahıyla Molla Halil temelde Eş'arîliğe bağlı kalırken, Eş’arî geleneğinde nadir rastlanan bir yaklaşımla kabir hayatında azap olduğu gibi aynı şekilde mümin ve salih kişiler için nimetler de olduğunu zikreder.

Yaşadığı dönemde bölgenin saygın uleması arasında ismi zikredilen Molla Halil, itikadî görüşleri itibarı ile Eş'ari geleneğini yansıtan bir medreselidir. Bilindiği üzere Türkiye'de genel anlamda itikadî gelenek Maturidî düşüncesine yaslanır. Ancak Doğu Anadolu medreselerinde Şafîi-Eşarî geleneği çok daha yaygın olup diğer pek çok medrese ulemasının eserlerinde görüldüğü gibi Molla
Halil'in eserlerinde de bu gelenek öne çıkmıştır. Kabir hayatı özelinde hazırlamış olduğumuz bu makale, Molla Halil'in Eş'arî geleneğe bağlılığını gösteren bir başka çalışma mahiyetindedir.

\section{Kaynakça}

Ahmed b. Hanbel. Müsned, 50 Cilt. nşr. Şuayb el-Arnaût vd. Beyrut.

Askalânî, İbn Hacer. (ts.). el-Cevâbü'l-Kâfî ani's-Suâli'lHâfî. el-Mektebetü'l-İslâmiyye. Diyarbakır.

Atalay, Ömer. (1946). Siirt Tarihi. Çeltut Matbaası. İstanbul.

Buhârî, Ebu Abdullah b. Muhammed b. İsmail. (1992). esSahih. I-VIII. İstanbul.

Bursalı Mehmet Tahir. (ts.). Osmanlı Müellifleri. I-II. A. Fikri Yavuz. İsmail Özen. İstanbul.

Cevherî Ebu Nasr İsmail b. Hammâd. (2009). es-Sihâh. IVI. Kahire: Dâru'l-Hadis.

Cürcânî. Seyyid Şerif. (1971). Şerhul-Mevâkıf. I-IV. Beyrut: Dâru'l-Kütübi'l-İlmiye.

Demirci, Kürşat. (2001). "Kabir”, Dİ, Cilt: XXIV, İstanbul.

Duveyhî, Ali b. Sa'd b. Sâlih. (1996). Ârâu'l-Mu'tezile elUsûliyye, Mektebetu'r-Rüşd, Riyad.

Ebu Davud. (1992). Süleyman b. el-Eş'as. es-Sicistânî. esSünen. I-V. İstanbul.

Ebu Ubeyde. Ma'mer b. el-Müsennâ. Mecâzü'l-Kur'ân. III. Meketebetü'l-Hâncî, Kahire.

Eş'arî. Ebu'l-Hasen Ali b. İsmail. (1409H.). el-İbâne an Usûli'd-Diyâne, el-Câmiatu'l-İslâmiyye. Medine.

Ferâhîdî, el-Halil b. Ahmed (2003). Kitâbü'l-Ayn. Dâru'lKütübi'l-İlmiyye, I-IV, Beyrut.

Firûzabâdî, Mecîdüddin (2008). el-Kâmûsü'l-Muhît. I-XIV. Dâru'l-Hadis. Kahire.

Goranî, Molla İlyas Bin İbrahim. (ts.). Hâşiyetü alâ Şerhi'lAkâid li Taftazânî. thk. Muhammed Can. Daruşşafaka. İstanbul

İbn Düreyd. Ebu Bekir Muhammed b. El-Hüseyin (1987). Cemheratü'l-Lüğa. I-III. Dâru'l-İlm li’l-Melâyîn. Beyrut.

İbn Ebi'l-İzz. Şerhu'l-Akîdeti't-Tahâviyye. nşr. Şuayb elArnavud. Şam.

İbn Fâris. Ebü'l-Hüseyin Ahmed (1989). Mu'cemü Mekâyîsi'l-Lüğa. I-VI. Dâru'l-Fikr.

İbn Mâce. Ebu Abdillah Muhammed b. Yezid el-Kazvînî, (1992). es-Sünen. İstanbul.

İbrahim Harrânî. (1427 h.). Tuhfetu'l-İhvân'l-Medresiyye fì Terâcim-i Ba'zi Musannifi'l-Kütübi'd-Dirâsiyye. Tillo. 
Kâdî Abdulcebbâr. Ebu'l-Hasen Abdulcebbar b. Ahmed b. Halil b. Abdillah el-Hemedânî el-Esedâbâdî (1974). Tabakâtu'l-Mu'tezile: Kitabü Fadli'l-I'tizâl ve Tabakati'l-Mu'tezile ve Mübâyenetuhüm li Sâiri'lMuhâlifîn (nşr. Fuad Seyyid), (Fadlu'l-i'tizâl ve Tabakatu'l-Mu'tezile içinde), ed-Dâru't-Tûnisiyye li'n-Neşr. Tunus.

Kazan, Faruk. (2013). Molla Halil'in Bilgi ve Varlık Anlayışı. Diyarbakır.

Koğî, Ahmet Hilmi. (ts.). Rehber-i Avâm. İhsan Yayınları.

Komisyon (1971). Şurûh ve Havâşi el-Akâidi Nesefiye. Dârül-Kütübi'l-İlmiyye. Beyrut.

Makrizî, Ebu'l-Abbâs Takiyyuddîn Ahmed b. Ali (845/1442). (ts.). el-Mevâuz ve'l-İ'tibâr bi Zikri'l-Hitat ve'l-Âsâr. Dâru Sâdır. Beyrut.

Molla Fudayl. Terceme. Zokayt Medresesi Kütüphanesi. Numarasiz.

Molla Halil. (2013). Tesisü Kavâidi'l-Akâid. Nubihar Yayınları. İstanbul.

Molla Halil. (ts.). Nehcü'l-Enâm. İhsan Yayınları.

Müslim. Ebü'l-Hüseyin Müslim b. el-Haccâc el-Kuşeyrî. (1992). Sahih-i Müslim. İstanbul.

Pakiş. Ömer (1996). Molla Halil es-Siirdî ve Tefsirciliği. Basılmamış Yüksek Lisâns Tezi. Marmara Üniversitesi Sosyal Bilimler Enstitüsü. İstanbul.
Pakiş. Ömer. (2005). "Molla Halil Siird̂̂”, DİA, Cilt: XXX, İstanbul.

Pezdevî, Ebu'l-Yüsr Muhammed b. Muhammed b. Hüseyn (1980). Ehl-i Sünnet Akaidi (tr. Şerafeddin Gölcük). Kayıhan. İstanbul.

Polat, Fethi Ahmet, (2009). Íslam Tefsir Geleneğinde Akılcı Söyleme Yönelik Eleştiriler. İz Yayıncılık. İstanbul.

Süyûtî. Celaleddîn. (2013). thk. Şeyh Ahmet Karid elMezidi. Daru'l-Kütübi'l-İlmiyye Beyrut.

Süyûtî. Celaleddîn. Kitâbu Itmâmü'd-Dirâye li Kurrâi'nNikâye. Beyrut.

Taftazânî. Mesud bin Ömer. (2017). Şerhu'l-Akâid. thk. Muhammed Can. Şefakat Yayıncılık. İstanbul.

Taftazânî. Sa'deddin. (1998). Şerhu'l-Makâsıld. thk. Abdurrahman Umeyre. Salih Musa Şeref. Âlemü'lKütüb. Beyrut.

Tekin. Serkan. (2017). "XVIII- XX. Asırlarda Siirt Bölgesinde Yapılan Kelam Çalışmaları". Yüksek Lisans Tezi. Danışman: Mehmet Ruzibaki. İstanbul Sabahattin Zaim Üniversitesi Temel İslâm Bilimleri Anabilim Dalı Kelam Bilim Dalı. İstanbul.

Tirmizî. Ebu İsa Muhammed b. Sevre. (1992) es-Sünen. İstanbul.

Toprak. Süleyman. (2001). "Kabir”, DIA, Cilt: XXIV, İstanbul. 